\title{
PENENTUAN PERIODE KRITIS TANAMAN BAWANG MERAH (Allium cepa var. aggregatum L.) AKIBAT PERSAINGAN DENGAN GULMA DI KABUPATEN SUBANG
}

\section{DETERMINATION OF CRITICAL PERIOD PLANTS ONION (Allium cepa var. Aggregatum l.) AS A RESULT OF COMPETITION WITH WEEDS IN SUBANG}

\author{
Asep Ikhsan Gumelar ${ }^{1}$, Frengky Arya Saputra ${ }^{2}$ \\ ${ }^{1}$ Program Studi Agroteknologi Fakultas Pertanian Universitas Timor \\ Jalan Eltari Km 9, Kota Kefamenanu Nusa Tenggara Timur \\ ${ }^{2}$ Program Studi Agroteknologi Fakultas Pertanian Universitas Subang \\ Jalan RA. Kartini Km 3 Subang Jawa Barat
}

Korespondensi : gumelar.ikhsan@unimor.ac.id

\begin{abstract}
ABSTRAK
Tujuan dari penelitian ini adalah untuk mempelajari penentuan periode kritis tanaman bawang merah yang diakibatkan oleh persaingan dengan gulma sehingga dapat ditetapkan waktu penyiangan yang paling tepat sehingga dapat diperoleh pertumbuhan dan hasil yang terbaik. Percobaan dilaksanakan di desa Tenjolaya, kecamatan Kasomalang, kabupaten Subang dengan ketinggian tempat $1.000 \mathrm{~m}$ diatas permukaan laut, jenis tanah Andisol, tipe curah hujan termasuk C (agak basah) menurut perhitungan Schmidt dan Ferguson (1951). Rancangan percobaan yang digunakan adalah rancangan acak kelompok (RAK) yang terdiri dari delapan perlakuan, yakni : A. Disiangi 2 Minggu Setelah Tanam; B. Disiangi 4 Minggu Setelah Tanam; C. Disiangi 6 Minggu Setelah Tanam; D. Disiangi 8 Minggu Setelah Tanam; E. Tanpa disiangi 2 Minggu Setelah Tanam; F. Tanpa disiangi 4 Minggu Setelah Tanam; G. Tanpa disiangi 6 Minggu Setelah Tanam; dan H. Tanpa disiangi 8 Minggu Setelah Tanam. Hasil penelitian menunjukkan bahwa periode kritis tanaman bawang merah akibat persaingan dengan gulma adalah 4 hingga 6 Minggu Setelah Tanam.
\end{abstract}

Kata kunci : Periode Kritis, Gulma, Bawang Merah

\begin{abstract}
The purpose of this study was to study the determination of the critical period of shallot plants caused by competition with weeds so that the most appropriate weeding time can be determined so that the best growth and yield can be obtained. The experiment was carried out in Tenjolaya village, Kasomalang sub-district, Subang district with an altitude of $1,000 \mathrm{~m}$ above sea level, Andisol soil type, rainfall type including C (slightly wet) according to the calculations of Schmidt and Ferguson (1951). The experimental design used was a randomized block design (RBD) consisting of eight treatments, namely: A. Illuminated for 2 weeks after planting; B. Lighted 4 Weeks After Planting; C. Lighted 6 Weeks After Planting; D. Prepared 8 Weeks After Planting; E. Without weeding 2 weeks after planting; F. Without weeding 4 weeks after planting; G. Without weeding 6 Weeks After Planting; and H. Without weeding 8 weeks after planting. The results showed that
\end{abstract}


the critical period for shallot plants due to competition with weeds was 4 to 6 weeks after planting.

Keywords : Critical Period, Weed, Red Chili

\section{PENDAHULUAN}

Sayuran merupakan salah satu tanaman hortikultura yang banyak mengandung vitamin dan mineral. Potensi produksi bawang merah (Allium cepa var. ascalonicum) di Indonesia mencapai lebih dari $20 \mathrm{t} \mathrm{ha}^{-1}$, akan tetapi produktivitas bawang merah nasional pada tahun 2013 tercatat sebesar 10,22 $\mathrm{t}$ $\mathrm{ha}^{-1}$ (Bappenas 2015). Bawang merah (Allium cepa var. aggregatum L.) dapat tumbuh baik di dataran tinggi maupun dataran rendah sepanjang tahun, baik pada musim hujan maupun pada musim kemarau cukup mendapat air. Musim kemarau selain tanaman bawang merah dapat tumbuh dengan baik, tetapi gulma yang tumbuh juga akan meningkat, terutama pada lahan yang diolah masih terdapat biji gulma yang terpendam dibawah permukaan tanah. Menurut Sandjaja (2010), bahwa sayuran adalah makanan nabati yang merupakan sumber zat gizi vitamin dan mineral yang dibutuhkan oleh tubuh manusia.

Tanaman bawang merah yang sering disebut juga bawang bakung, yaitu sejenis bahan masakan yang sudah dikenal rakyat Indonesia. Selain itu bawang merah juga sering dipakai dalam campuran masakan antara lain dadar telur, sop, soto dan lain-lain.

Komposisi dan kandungan gizi dalam 100 g bawang merah adalah kalori 29 $\mathrm{kal}$, protein $1,2 \mathrm{~g}$ lemak $0,4 \mathrm{~g}$, karbohidrat $6 \mathrm{~g}$, serat dan abu 1,4 g, kalsium $35 \mathrm{mg}$, posfor $38 \mathrm{mg}$, zat besi $3,2 \mathrm{mg}$ vitamin $910 \mathrm{SI}$, vitamin B 0,08 $\mathrm{mg}$, vitamin B2 $0,0 \mathrm{mg}$, vitamin C 48 mg, dan sisanya air Direktorat Gizi Departemen kesehatan RI,1981.

Salah satu penyebab rendahnya hasil bawang merah di Indonesia adalah adanya gangguan gulma yang meliputi kompetisi fisik memperebutkan kebutuhan hidup (air, unsur hara, udara, cahaya matahari, dan tempat tumbuh), kompetisi kimia (alleopati) ataupun oleh peranan gulma yang menjadi tanaman inang hama dan penyakit pada tanaman.

Besarnya kerugian yang diakibatkan oleh gulma pada tiap tanaman budidaya mencapai 33,8\%. Besarnya kerugian yang diakibatkan oleh gulma pada tiap tanaman berbeda-beda. Gulma yang tidak disiang/dikored pada tanaman tomat dapat menurunkan hasil sebesar 50 $\%$, pada tanaman bawang merah dapat menurunkan hasil sebesar 50-80 \%. Gulma sering disebut sebagai tumbuhan pengganggu yang pada umumnya tumbuh di waktu dan tempat yang tidak tetap (Sembodo, 2010). Maka pengendalian gulma sangat penting untuk menjaga pertumbuhan dan perkembangan tanaman bawang maksimal.

Hasil yang menurun akibat gulma dapat dihindari jika diadakan usahausaha pengendalian. Ada beberapa cara pengendalian gulma di antaranya cara mekanik, cara biologis, cara kultur teknis, dan cara kimia. Agar memperoleh hasil bawang merah yang tinggi, perlu diadakan pengendalian terhadap jasad pengganggu (gulma). Penyiangan merupakan salah satu usaha untuk menjaga tanaman dari jasad pengganggu yaitu gulma. Penyiangan merupakan salah satu usaha pengendalian gulma 
cara mekanik di pertanaman bawang merah.

Penyiangan di pertanaman bawang merah harus dilakukan tepat pada waktunya. Bila penyiangan ini tidak dilakukan maka akan mengakibatkan meningkatkan persaingan antara gulma dengan tanaman bawang merah sehingga akan menghambat pertumbuhan dan mengurangi hasil tanaman bawang merah.

Tujuan dari penelitian ini adalah untuk mempelajari penentuan periode kritis tanaman bawang merah akibat persaingan dengan gulma sehingga bisa ditetapkan waktu penyiangan yang paling tepat sehingga dapat diperoleh pertumbuhan dan hasil bawang merah yang terbaik. Penelitian ini diharapkan dapat memberikan informasi tentang periode kritis tanaman bawang merah akibat persaingan dengan gulma. Di samping itu, dari hasil penelitian dapat dijadikan acuan untuk penelitian berikutnya.

\section{BAHAN DAN METODE}

Percobaan ini dilaksanakan di desa Tenjolaya, kecamatan Kasomalang, kabupaten Subang. Tempat percobaan ini terletak pada ketinggian $1.000 \mathrm{~m}$ di atas permukaan laut dengan jenis tanah Andisol. Daerah ini termasuk ke dalam tipe curah hujan C (agak basah) berdasarkan perhitungan Schmidt dan Ferguson (1951). Waktu percobaan dilakukan pada bulan Juni sampai dengan Agustus 2016.

Bahan yang digunakan dalam percobaan ini terdiri pupuk kandang sapi, pupuk Urea $(45 \% \mathrm{~N}), \mathrm{SP}-36(36 \%$ $\left.\mathrm{P}_{2} \mathrm{O}_{5}\right)$, KCI $\left(60 \% \quad \mathrm{~K}_{2} \mathrm{O}\right)$, Insektisida Profenofos (Curacron 500 EC), fungisida Mankozeb (Dhitane M 45 WP), benih bawang merah lokal Subang. Alat-alat yang digunakan sabit, kored, cangkul, timbangan, oven pengering, tali rapia, ajir, kuadrat baja $(0,5 \mathrm{~m} \times 0,5 \mathrm{~m})$, penggaris, jangka sorong, hand sprayer, gelas ukur, corong, gembor, ember plastik dan kantong plastik.

Penelitian ini menggunakan rancangan acak kelompok sederhana yang terdiri dari delapan perlakuan penyiangan gulma adalah sebagai berikut :

A: Disiang 2 MST,

B: Disiang 4 MST,

C: Disiang 6 MST,

D: Disiang 8 MST,

E: Tanpa disiang $2 \mathrm{MST}$,

F: Tanpa disiang 4 MST,

G: Tanpa disiang 6 MST,

$\mathrm{H}$ : Tanpa disiang $8 \mathrm{MST}$

Ukuran petak percobaan adalah ukuran petak $2 \mathrm{~m}$ x 1,2 $\mathrm{m}$ dengan jarak antar ulangan $50 \mathrm{~cm}$ dan jarak antar petak $30 \mathrm{~cm}$, sehingga lahan yang diperlukan untuk percobaan ini seluas 75 $\mathrm{m}^{2}$. Lahan percobaan dibuat menjadi empat blok ulangan dan setiap blok dibagi ke dalam delapan petak perlakuan dengan ukuran yang sama, kemudian setiap perlakuan ditempatkan dalam petak percobaan secara acak, sehingga secara keseluruhan terdapat 32 petak percobaan.

Pengamatan penunjang adalah pengamatan yang datanya tidak diuji secara statistik, tetapi memberikan informasi dalam membahas hasil percobaan seperti pengamatan mengenai data curah hujan selama percobaan, analisis vegetasi sebelum percobaan.

Pengamatan utama adalah pengamatan yang datanya diuji secara statistik yang dilakukan pada tanaman contoh yang ditentukan secara acak sederhana. Pengamatan utama meliputi : Bobot kering tiap jenis gulma meliputi :

1. Jenis-jenis gulma 
2. Bobot kering gulma $\left(\mathrm{g} / 0,25 \mathrm{~m}^{2}\right)$

1) Berdaun lebar

2) Teki

3) Berdaun sempit

$$
\text { Total }=\ldots \ldots g \mathrm{~g} / 0,25 \mathrm{~m}^{2}
$$

Pengamatan bobot kering gulma dilakukan pada waktu masing-masing perlakuan mulai 2 minggu setelah tanam. Pengambilan gulma diambil dari tiap petak percobaan dengan alat kuadrat baja $(0,5 \mathrm{~m} \times 0,5 \mathrm{~m})=0,25 \mathrm{~m}^{2}$ Pengambilan dengan cara mencabut gulma, kemudian dikelompokan dengan species yang ada. Gulma yang telah diambil dikeringkan dalam oven pengering pada suhu $80^{\circ} \mathrm{C}$ sampai bobot keringnya tetap.

Parameter percobaan ini diantaranya ; Tinggi tanaman (diukur pada umur 15 HST dan 45 HST), Jumlah daun per rumpun (diukur pada umur 15 HST dan 45 HST), Bobot umbi segar (g/rumpun), Bobot umbi kering simpan (k.a. 80\%) (g/rumpun), Jumlah umbi/rumpun, Diameter umbi rata-rata $(\mathrm{cm})$.

\section{HASIL DAN PEMBAHASAN}

\section{Tinggi Tanaman}

Dapat diketahui bahwa pertumbuhan tinggi tanaman bawang merah tidak menunjukkan perbedaan nyata baik antara yang disiang maupun tanpa penyiangan masing-masing pada perlakuan A (disiangi $2 \mathrm{MST}$ ), B (disiangi $4 \mathrm{MST}$ ), C (disiangi $6 \mathrm{MST}$ ), dan D (disiangi 8 MST) pada umur 15 dan 45 HST. Perbedaan tinggi tanaman disebabkan oleh besarnya intensitas cahaya yang diterima oleh tanaman dan berkaitan dengan hormon tanaman yaitu auksin. Menurut Pantilu et al. (2012) menyatakan bahwa tanaman yang tumbuh di bawah naungan memperoleh intensitas cahaya yang rendah sehingga hormon auksin tidak mengalami kerusakan. Kompetisi cahaya antara tanaman pokok dan gulma dipengaruhi oleh kecepatan pertumbuhan pada stadia awal dari tanaman atau gulma (Tabel 1).

Tabel 1. Tinggi Tanaman Bawang Merah Akibat Persaingan dengan Gulma pada Umur 15 HST dan 45 HST

\begin{tabular}{llc}
\hline \multirow{2}{*}{ Perlakuan } & \multicolumn{2}{c}{ Tinggi Tanaman $(\mathrm{cm})$} \\
\cline { 2 - 3 } & $15 \mathrm{HST}$ & $45 \mathrm{HST}$ \\
\hline A (disiang 2 MST) & $25,81 \mathrm{a}$ & $30,99 \mathrm{a}$ \\
B (disiang 4 MST) & $25,23 \mathrm{a}$ & $30,91 \mathrm{a}$ \\
C (disiang 6 MST) & $25,49 \mathrm{a}$ & $31,59 \mathrm{a}$ \\
D (disiang 8 MST) & $25,87 \mathrm{a}$ & $31,90 \mathrm{a}$ \\
E (tanpa disiang 2 MST) & $25,39 \mathrm{a}$ & $31,60 \mathrm{a}$ \\
F (tanpa disiang 4 MST) & $25,34 \mathrm{a}$ & $31,62 \mathrm{a}$ \\
G (tanpa disiang 6 MST) & $25,72 \mathrm{a}$ & $31,38 \mathrm{a}$ \\
H (tanpa disiang 8 MST) & $25,36 \mathrm{a}$ & $31,78 \mathrm{a}$ \\
\hline
\end{tabular}

Keterangan :Angka yang ditandai dengan huruf yang sama pada kolom yang sama berbeda tidak nyata menurut Uji jarak berganda Duncan 5\%.

HST $=$ hari setelah tanam

MST = minggu setelah tanam

\section{Jumlah Daun per Rumpun}

Dapat diketahui bahwa jumlah daun bawang merah di antara perlakuan A (disiangi $2 \mathrm{MST}$ ), B (disiangi $4 \mathrm{MST}$ ), C (disiangi $6 \mathrm{MST}$ ), D (disiangi $8 \mathrm{MST}$ ), E (tanpa disiangi 2 MST), F (tanpa disiangi 
4 MST), G (tanpa disiangi 6 MST) dan H (tanpa disiangi 8 MST) tidak menunjukkan berbeda nyata pada umur 15 dan 45 HST, Namun pada data (Tabel 2) jumlah daun terbanyak yitu perlakuan $\mathrm{E}=26,86$ dan perlakuan $F=26,82$. Hal ini disebabkan oleh perlakuan penyiangan gulma yang disiang sejak awal pertumbuhan hingga umur 6 HST, sehingga pertumbuhan bawang merah tumbuh normal tidak mengalami persaingan dengan gulma. Dalam hal ini pertumbuhan gulma tidak menaungi tanaman bawang merah sehingga cahaya matahari masih bisa leluasa masuk ke bagian daun bawang merah. Demikian juga keadaan yang dialami oleh perlakuan B dan D (Tabel 2). Ini menunjukan semua perlakuan tidak mempengaruhi jumlah daun.

Tabel 2. Jumlah Daun Bawang Merah Akibat Persaingan dengan Gulma pada Umur 15 HST dan 45 HST

\begin{tabular}{lcc}
\hline \multirow{2}{*}{ Perlakuan } & \multicolumn{2}{c}{ Jumlah Daun $(\mathrm{cm})$} \\
\cline { 2 - 3 } & $15 \mathrm{HST}$ & $45 \mathrm{HST}$ \\
\hline A (disiang 2 MST) & $14,85 \mathrm{a}$ & $25,40 \mathrm{a}$ \\
B (disiang 4 MST) & $13,98 \mathrm{a}$ & $26,14 \mathrm{a}$ \\
C (disiang 6 MST) & $14,92 \mathrm{a}$ & $26,29 \mathrm{a}$ \\
D (disiang 8 MST) & $14,32 \mathrm{a}$ & $26,31 \mathrm{a}$ \\
E (tanpa disiang 2 MST) & $14,46 \mathrm{a}$ & $26,86 \mathrm{a}$ \\
F (tanpa disiang 4 MST) & $14,76 \mathrm{a}$ & $26,82 \mathrm{a}$ \\
G (tanpa disiang 6 MST) & $14,52 \mathrm{a}$ & $26,10 \mathrm{a}$ \\
H (tanpa disiang 8 MST) & $14,22 \mathrm{a}$ & $26,14 \mathrm{a}$ \\
\hline
\end{tabular}

Keterangan :Angka yang ditandai dengan huruf yang sama pada kolom yang sama berbeda tidak nyata menurut Uji jarak berganda Duncan 5\%.

HST $=$ hari setelah tanam

MST = minggu setelah tanam

\section{Bobot Umbi Segar (g/rumpun), Bobot Umbi Kering, dan Jumlah Umbi per Rumpun dan Diameter}

Dari Tabel 3 dan 4 dapat diketahui bahwa apabila gulma disiang sejak tanam hingga umur 6 MST (C) ternyata dapat menunjukkan jumlah umbi bawang merah per rumpun paling banyak bila dibandingkan dengan jumlah umbi yang ditampilkan oleh perlakuan lainnya. Kemudian disusul oleh perlakuan yang disiang hingga 8 MST (D) dan tanpa disiang hingga umur 2 MST (E). Peristiwa ini linier ( sejalan) dengan variabel bobot umbi segar dan bobot umbi kering simpan per rumpun yang masing-masing tidak berbeda dengan perlakuan gulma yang disiang sejak awal pertumbuhan hingga umur 4 MST (B). Demikian juga jika dihubungkan dengan bobot kering gulma total termasuk berat gulma yang ringan (lihat Tabel 6), jadi pertumbuhan bawang merah pada perlakuan B (disiangi 4 MST), $\mathrm{C}$ (disiangi 6 MST) dan D (disiangi 8 MST) tidak mengalami persaingan yang berarti dari gulma. Menurut Menurut Moenandir (2010) gulma dapat menyerap nitrogen dua kali lebih banyak daripada tanaman. Peristiwa ini diperlihatkan oleh perlakuan A (disiang hingga $2 \mathrm{MST}$ ), G, dan $\mathrm{H}$ (tanpa disiang masing-masing hingga 6 dan 8 MST) di mana bobot gulma totalnya termasuk paling berat dibandingkan dengan bobot gulma pada perlakuan lainnya (Tabel 6). Jadi dengan demikian apabila pertanaman bawang merah yang disiang 
sejak awal pertumbuhan hingga 4 dan 6 HST tidak mengalami persaingan yang berarti dari gulma. Gulma yang berada diarea pertanaman lebih lama menyebabkan terjadinya kompetisi dalam memanfaatkan unsur-unsur hara yang ada dilingkungan pertanaman.

Pada Tabel 3 dapat diketahui bahwa perlakuan $\mathrm{C}$ (penyiangan gulma sejak awal hingga umur 6 MST) menunjukkan diameter umbi bawang merah rata-rata lebih besar dari pada perlakuan A (disiang hingga $2 \mathrm{MST}$ ), $\mathrm{E}$ (tanpa disiang hingga 2 MST) dan F (tanpa disiang hingga 4 MST), tetapi tidak berbeda dengan B (disiang hingga 4 MST), D (disiang hingga 8 MST), dan G (tanpa disiang hingga 6 MST). Menurut Nurjannah (2003) tanaman yang mengalami tekanan berupa stres air, suhu, cahaya matahari, ataupun hara dapat mengakibatkan hubungan antara source dan sink terganggu.

Tabel 3. Jumlah Umbi per Rumpun dan Diameter Umbi Bawang Merah Rata-rata Akibat Persaingan dengan Gulma

\begin{tabular}{lcc}
\hline \multicolumn{1}{c}{ Perlakuan } & $\begin{array}{c}\text { Jumlah Umbi Per } \\
\text { Rumpun (Buah) }\end{array}$ & $\begin{array}{c}\text { Diameter Umbi Rata- } \\
\text { rata }(\mathrm{cm})\end{array}$ \\
\hline A (disiang 2 MST) & $7,28 \mathrm{a}$ & $2,0 \mathrm{a}$ \\
B (disiang 4 MST) & $8,22 \mathrm{~b}$ & $2,10 \mathrm{ab}$ \\
C (disiang 6 MST) & $10,02 \mathrm{~d}$ & $2,17 \mathrm{~b}$ \\
D (disiang 8 MST) & $8,89 \mathrm{c}$ & $2,02 \mathrm{ab}$ \\
E (tanpa disiang 2 MST) & $8,88 \mathrm{c}$ & $2,0 \mathrm{a}$ \\
F (tanpa disiang 4 MST) & $7,39 \mathrm{a}$ & $1,95 \mathrm{a}$ \\
G (tanpa disiang 6 MST) & $6,81 \mathrm{a}$ & $2,02 \mathrm{ab}$ \\
H (tanpa disiang 8 MST) & $6,82 \mathrm{a}$ & $1,93 \mathrm{a}$ \\
\hline
\end{tabular}

Keterangan :Angka yang ditandai dengan huruf yang sama pada kolom yang sama berbeda tidak nyata menurut Uji jarak berganda Duncan 5\%.

HST $=$ hari setelah tanam

MST = minggu setelah tanam

Tabel 4. Bobot Umbi Segar dan Bobot Umbi Kering Simpan Bawang Merah Akibat Persaingan dengan Gulma

\begin{tabular}{lcc}
\hline Perlakuan & $\begin{array}{c}\text { Bobot Umbi Segar Per } \\
\text { Rumpun } \\
(\mathrm{g})\end{array}$ & $\begin{array}{c}\text { Bobot Umbi Kering } \\
\text { Simpar Per Rumpun } \\
(\mathrm{g})\end{array}$ \\
\hline A (disiang 2 MST) & $23,88 \mathrm{a}$ & $19,36 \mathrm{a}$ \\
B (disiang 4 MST) & $36,77 \mathrm{c}$ & $29,48 \mathrm{c}$ \\
C (disiang 6 MST) & $36,86 \mathrm{c}$ & $29,57 \mathrm{c}$ \\
D (disiang 8 MST) & $34,64 \mathrm{~b}$ & $27,30 \mathrm{~b}$ \\
E (tanpa disiang 2 MST) & $33,98 \mathrm{~b}$ & $26,88 \mathrm{~b}$ \\
F (tanpa disiang 4 MST) & $25,14 \mathrm{a}$ & $20,11 \mathrm{a}$ \\
G (tanpa disiang 6 MST) & $23,88 \mathrm{a}$ & $19,12 \mathrm{a}$ \\
H (tanpa disiang 8 MST) & $24,34 \mathrm{a}$ & $19,40 \mathrm{a}$ \\
\hline
\end{tabular}

Keterangan :Angka yang ditandai dengan huruf yang sama pada kolom yang sama berbeda tidak nyata menurut Uji jarak berganda Duncan 5\%.

MST = minggu setelah tanam 
Bobot Kering Gulma Berdaun Sempit, Berdaun Lebar dan Teki (g/0,25 m2) Akibat Persaingan dengan Tanaman Bawang Merah

Tabel 5 memperlihatkan bahwa bobot kering gulma berdaun sempit atau golongan rumput yang didominansi oleh Eleusine indica (jampang) menunjukkan bobot yang paling berat bila dibandingkan dengan bobot gulma yang ditampilkan oleh perlakuan lainnya. Hal ini disebabkan gulma yang tumbuh sejak awal tumbuh hingga 2 MST masih sedikit sehingga gulma berdaun sempit tumbuh subur sejak bawang merah berumur 2 MST hingga panen. Sedangkan gulma yang berdaun lebar yang didominansi oleh Ageratum cony zoides (wedus putih), di mana perlakuan tanpa penyiangan dari awal tumbuh hingga
8 MST menunjukkan bobot kering gulma lebih berat daripada perlakuan lainnya, kecuali dengan perlakuan gulma yang disiang dari awal tumbuh hingga umur bawang merah 2 MST dan tanpa penyiangan hingga umur 6 MST. Bobot kering gulma golongan teki yang didominansi oleh Cyperus brevifolius pada perlakuan A(disiang hingga 2 MST), G (tanpa disiang hingga 6 MST) dan $\mathrm{H}$ (tanpa disiang hingga 8 MST) lebih berat dari pada perlakuan lainnya. Gulma yang berada diarea pertanaman lebih lama menyebabkan terjadinya kompetisi dalam memanfaatkan unsur-unsur hara yang ada dilingkungan pertanaman. Menurut Moenandir (2010) gulma dapat menyerap nitrogen dua kali lebih banyak daripada tanaman.

Tabel 5. Bobot Kering Gulma Berdaun Sempit, Berdaun Lebar dan Teki (g/0,25 m2) Akibat Persaingan dengan Tanaman Bawang Merah

\begin{tabular}{lccc}
\hline & \multicolumn{3}{c}{ Bobot Kering Gulma $\left(\mathrm{g} / 0,25 \mathrm{~m}^{2}\right)$} \\
\cline { 2 - 4 } \multicolumn{1}{c}{ Perlakuan } & $\begin{array}{c}\text { Berdaun sempit } \\
\text { (Eleusine indica) }\end{array}$ & $\begin{array}{c}\text { Berdaun Lebar } \\
\text { (Ageratum cony } \\
\text { zoides) }\end{array}$ & $\begin{array}{c}\text { Teki } \\
\text { (Cyperus } \\
\text { brevifolius) }\end{array}$ \\
\hline A (disiang 2 MST) & $6,65 \mathrm{~b}$ & $9,43 \mathrm{~cd}$ & $8,17 \mathrm{c}$ \\
B (disiang 4 MST) & $3,94 \mathrm{a}$ & $6,62 \mathrm{~b}$ & $5,09 \mathrm{a}$ \\
C (disiang 6 MST) & $4,88 \mathrm{a}$ & $4,98 \mathrm{a}$ & $5,96 \mathrm{~b}$ \\
D (disiang 8 MST) & $4,60 \mathrm{a}$ & $5,80 \mathrm{ab}$ & $6,07 \mathrm{~b}$ \\
E (tanpa disiang 2 MST) & $4,18 \mathrm{a}$ & $5,57 \mathrm{ab}$ & $5,69 \mathrm{ab}$ \\
F (tanpa disiang 4 MST) & $4,06 \mathrm{a}$ & $6,96 \mathrm{c}$ & $4,95 \mathrm{a}$ \\
G (tanpa disiang 6 MST) & $6,34 \mathrm{~b}$ & $9,36 \mathrm{~cd}$ & $7,76 \mathrm{c}$ \\
H (tanpa disiang 8 MST) & $6,77 \mathrm{~b}$ & $10,5 \mathrm{~d}$ & $8,13 \mathrm{c}$ \\
\hline
\end{tabular}

Keterangan :Angka yang ditandai dengan huruf yang sama pada kolom yang sama berbeda tidak nyata menurut Uji jarak berganda Duncan 5\%.

MST = minggu setelah tanam

Kerapatan gulma yang tinggi akan diimbangi oleh peningkatan bobot kering gulma seiring dengan bertambahnya waktu tumbuh gulma (Latifa et al., 2015). Persyaratan tumbuh yang hampir sama tersebut dapat mengakibatkan adanya kompetisi antara gulma dan tanaman pokok.

\section{Bobot Kering Gulma Total}

Dari Tabel 6 dapat diketahui bahwa A (disiang hingga 2 MST), G (disiang hingga 6 MST), dan $\mathrm{H}$ (disiang hingga 8 MST) menunjukkan bobot kering gulma lebih berat daripada kelima perlakuan lainnya. Hal ini dapat dimengerti bahwa penyiangan gulma sejak awal tumbuh 
hingga 2 MST kurang berpengaruh terhadap peningkatan bobot gulma total secara keseluruhan hingga panen bawang merah. Pertumbuhan gulma pada periode 0 - 2 MST masih sedikit, tetapi setelah 2 MST pertumbuhan gulma makin pesat. Pada perlakuan penyiangan gulma yang sangat terlambat seperti yang ditunjukkan oleh perlakuan $\mathrm{G}$ dan $\mathrm{H}$ dapat dipastikan laju pertumbuhan gulma semakin cepat sehingga penutupan gulma pada areal pertanaman gulma semakin cepat. Kerapatan gulma yang tinggi akan diimbangi oleh peningkatan bobot kering gulma seiring dengan bertambahnya waktu tumbuh gulma (Latifa et al., 2015). Keadaan ini sudah jelas akan sangat menurunkan bobot umbi bawang merah seperti yang diperlihatkan pada Tabel 4.

Berdasarkan keterangan di atas dapat diketahui bahwa penyiangan gulma yang dilakukan sejak awal pertumbuhan bawang merah hingga 4 dan 6 MST mampu menekan pertumbuhan gulma sehingga relatif tidak berpengaruh terhadap pertumbuhan jumlah daun dan hasil bawang merah, sedangkan tanpa penyiangan gulma dapat menekan pertumbuhan jumlah daun dan hasil bawang merah. Hal ini sesuai dengan hasil penelitian yang dilakukan oleh Jody Moenandir (1990) bahwa periode kritis pada tanaman bawang merah terjadi pada umur 4 hingga 6 MST. Awal pertumbuhan tanaman biasanya merupakan saat yang sangat rawan dalam persaingan. Gulma dengan banyak jenisnya dan bersifat kompetitif akan sangat merugikan pertumbuhan tanaman budidaya bila tidak dikendalikan dengan baik.

Tabel 6. Bobot Kering Gulma Total Akibat Persaingan Gulma dengan Tanaman Bawang Merah $\left(\mathrm{g} / 0,25 \mathrm{~m}^{2}\right)$

Keterangan :Angka yang ditandai dengan huruf yang sama pada kolom yang sama berbeda tidak nyata menurut Uji jarak berganda Duncan 5\%.

MST = minggu setelah tanam

\section{SIMPULAN}

Dari hasil analisis statistik dan pembahasan yang telah diuraikan di muka maka dapat ditarik kesimpulan :

1. Semakin lama keadaan tanaman bawang merah tanpa disiangi semakin meningkatkan pertumbuhan gulma sehingga dapat menurunkan pertumbuhan dan hasil bawang merah.

2. Periode kritis tanaman bawang merah terhadap persaingan dengan gulma adalah pada 4 hingga 6 minggu setelah tanam. 


\section{SARAN}

Dari hasil penelitian ini dapat disarankan apabila menanam bawang merah agar pertumbuhan dan hasilnya baik areal pertanaman harus bebas dari gulma, setidak-tidaknya sejak awal tanam hingga 4 atau 6 minggu setelah tanam untuk daerah penelitian dan sekitarnya.

\section{UCAPAN TERIMA KASIH}

Penulis mengucapkan terimakasih kepada Dosen senior Ir. Oih Al Alis Mihardja, MS, yang telah mendukung penelitian ini.

\section{DAFTAR PUSTAKA}

Amir Hamzah Sumintapura dan R. Suratno Iskandar. (1980). Pengantar Herbisida PT. Karya Nusantara. Jakarta.

Badan Perencanaan Pembangunan Nasional 2015, RPJM Bidang Pangan dan Pertanian 2015-2019, diunduh 15 Maret 2015, < http://www.bappenas.go.id >.

Direktorat Gizi Departemen Kesehatan RI. 1981. Komposisi bahan makan. Jakarta.

Dwidjoseputro. D. 1983. Dasar-dasar Fisiologi Tumbuhan. PT Gramedia. Jakarta

Firman Bangun 1988. Gulma Lahan Kering dan Pengendaliannya dalam Prosiding Seminar HIGI-UNILA.

Fryer, J. D. dan S. Matsunaka, Soichi. 1988. Penanggulangan Gulma Terpadu. Bina Aksara. Jakarta.

Hendro Sunaryono. 1987. Kunci Bercocok Tanam Sayuran Penting di Indonesia. Penerbit Sinar Baru. Jakarta.
Jody Moenandir. 1985. Weed Control as A Science. John Wiley and Sond Inc. New York.

Latifa, Y.R., M.D. Maghfoer dan E. Widaryanto. 2015. Pengaruh Pengendalian Gulma Terhadap Tanaman Kedelai (Glycine max (L.) Merril) Pada Sistem Olah Tanah. Jurnal Produksi Tanaman. 3(4): 311320.

Moenandir. 1988. Fisiologi Herbisida. Rajawali. Jakarta.

Moenandir J. 1990. Fisiologi Herbisida (Ilmu Gulma: Buku II) Rajawali Press. Jakarta.

Moenandir, J. 2010. Ilmu Gulma. Universitas Brawijaya Press. Malang.

Nurjannah, U. 2003. Pengaruh Dosis Herbisida Glifosat dan 2,4-D terhadap Pergeseran Gulma Tanaman Kedelai Tanpa Olah Tanah. Jurnal Ilmu-Ilmu Pertanian Indonesia. 5(1): 27-33.

Pantilu, L.I., F.R. Mantiri, N.S. Ai dan D. Pandiangan. 2012. Respon Morfologi dan Anatomi Kecambah Kacang Kedelai (Glycine max (L.) Merill) terhadap Intensitas Cahaya yang Berbeda. Jurnal Bioslogos. 2(2): 7987.

Rahmat Rukmana. 1995. Budidaya Bawang Merah. Kanisius. Jogjakarta.

Sandjaja. (2010). Gizi, Jakarta: PT Kompas Media Nusantara.

Sembodo, D. 2010. Gulma dan Pengelolaannya. Yogyakarta : Graha Ilmu.

Schmid, F. H. and J.H.A Ferguson. 1951. Rainfal Types Based on Wet Dryn Perios Ration for Indonesia With Westren New Guinea Verhandelingen No 156 Kementerian 
Perhubungan Djawatan Metereologi dan Geofisika. Jakarta.

Sugeng, H. R. 1981. Bercocok Tanam Sayuran. CV. Aneka. Bandung.

Sundaru, M., Mahyuddin, S., Bakar, J. 1976. Beberapa Jenis Gulma pada
Padi Sawah. Bogor : Lembaga Pusat Penelitian Pertanian. 